\title{
CHRYSTUS W SYMBOLACH CHRZEŚCIJAŃSKICH
}

1. Duchowe przyczyny powstania znaków chrześcijańskich.

Klejnotami głębi i dojrzałości kultury katolickiej są symbole pierwszych chrześcijan. Ażeby docenić ich wielkie i praktyczne znaczenie, należy zwrócić uwagę na atmosferę duchową, w której powstały. Początkiem bowiem sięgają najtrudniejszych czasów w dziejach Kościoła świętego. Powstały one wśród pienwszych katolików czynu, co zaczęli żyć z Chrystusem. Głębia prawdy, zawarta w symbolach pierwszych wyznawców Jezusa, była u nich przede wszystkim żywym faktem ich własnego życia wewnętrznego. Ta rzeczywistość przé̇ywania Chrystusa 'we własnym życiu wewnętrznym była źródłem apostolstwa, które wymagało bezustannego bodźca zewnętrznego. Były nim symbole chrześcijańskie. One to swoimi znakami przypominały fundamentalne prawwdy dogmatyczne wiary naszej. Budziły nie tyle zmysł piękna, ile głębię myśli Bożych. Były równocześnie wyrazem dużej łączności między wyznawcami, których wiązało realne braterstwo dziecięctwa Bożego i odwagi podjęcia trudu życia dla Boga i z Bogiem. Słowem, symbole pierwszych chrześcijan, to zewnętrzny wyraz wewnętrznej jednośdi myśli i ducha w Bogu. Miały one charakter wybitnie społeczny, a współczesne nazywanie ich symbolami liturgicznymi jest bardzo trafne. ,Lêi to ergon " ${ }^{1}$ ), jako źródłosłów wyrazu ,liturgia“, wywodzi się z greckiego języka i oznacza ,czyn dla ludu“, społeczny czyn. Symbole zaś liturgiczne nosiły właśnie ten wybitnie społeczny charakter, zachęcając i utwierdzając społecznego ducha w służbie Bożej.

Dla niektórych symbole były pustymi znakami, a pełne znaczenie posiadały tylko dla tych, co żyli z Chrystusem. Im zaś kitoś bardziej żył duchem Bożym, tym większą głębię odczytywał ze znaku świętego. Zależnie więc od głębi życia wewnętrznego poszczególnej jednostki symbol zawierał poza wyrażeniem obiektywnej prawdy tyle głębi, na ile natrafial w poszczególnej duszy ludzkiej.

Zrozumienie symbolu wymagało więc głębi myśli chrześcijańskiej ze względu na to, że obiektywnie wyrażał pewną prawdę dogmatyczną, ale pełnię jego treści subiektywnie odcyfrowali wierni przepojeni życiem wewnętrznym. Podobnie jak muzykę, czy plastykę przé̇yje

1) L ê i pochodzi od 1 a o s = lud; np. lê i t o n oznacza ,dom ludowy, gminny"; - to ergon $=$ praca, dzielo. 
osoba nie tylko znająca zasady danej dziedziny, ale o ile sama jest subtelna i rozwija w sobie wrażliwośé piękna. Symbol zatem mówił każdemu poza obiektywną prawdą tyle, ile znany mu był w przeżyciu i zżyciu się Jezus Chrystus własnej duszy. Trzeba było nie tylko znać prawdę świętych obcowania, ale przede wszystkim i równocześnie być duchowo zdrową i apostolsko czynną komórką Mistycznego Ciała Chrystusowego i partycypować nie tylko biernie, ale z całą aktywną świadomością w życiu Kościoła cierpiącego, walczącego i triumfującego. Psychologicznie biorąc, symbol poprzez zmysły wpływał na umysł, ale ostatecznie na życie wewnętrzne. Celem jego było, by dotarłszy rozumnie do wnętrza duszy ludzkiej - stanowić pobudke do urzeczywistnienia prawd Bożych w sobie i stałą zachętę do rozwoju ducha apostolskiego. Pozornie zdawać by się mogło, że - zewnętrznie biorąc - symbol nie był niczym specjalnym. Zawierał jednak w sobie to wielkie, realne $\mathrm{i}$ tajemnicze „,oś" — realizm nadprzyrodzonego życia z Bogiem na ziemi. Gdzie nie ma głebi, niewyrażalności ponadludzkiej, tam nie ma symbolu. Brak mu istotnych podstaw.

U progu dziejów Kościoła spostrzegamy jeszcze jeden moment życiowo ważny dla pierwszych wyznawców Jezusa. Strzegą się wśród żydów i pogan jako wrogów zewnętrznych, stali jednak uparcie na straży wolności ducha własnego, by się z czymkolwiek na świecie w sposób niepoprawny nie wiązać. Prześladowanie pierwszych chrześcijan, to wielkie rekolekcje wśród oderwania, wzgardy i odosobnienia ludzi, którym nie wolno było wypowiedzieć w pełni, co ich jednoczy. Nie u'mieli nawet wyrazić $\mathrm{w}$ pełni tego, co ich wiąże w organiczną całość. Powstają wiẹc wśród nich znaki - symbole. Posługują sie nimi w przeciwstawieniu do zewnętrznej smutnej rzeczywwistości. Służą zaś Królestwu, które nie jest z tego świata (Jan 18, 36) ; realizują pokój, którego świat nie daje (Jan 14,27$)$ i radują się, że dla imienia Jego ciępieć im dano.

\section{Pojęcie symbolu.}

Człowiek tak wielokrotnie posługuje się przeróżnymi znakami symbolami, że nawet nie zdaje sobie $\mathrm{z}$ tego częstokroć sprawy. Każda cyfra jest znakiem liczby. Każda litera znakiem dźwięku, każdy wyraz znakiem myśli, a każde słowo pisane znakiem pojęcia. Człowiek jest bowiem $\mathrm{z}$ istoty swej ,animal sociale“. Gdyby był samotny, nie potrzebowałby znaków. Jako jednostka społeczna musi się nimi jednak 
posługiwać, jako niezbędnym środkiem. ,Nic bowiem nie przenika do intelektu, co by uprzednio nie działało na zmysły“" ${ }^{2}$.

Wyraz ,symbol" pochodzi etymologicznie z jezzyka greckiego; słowo ,to symbolon" (od symballejn) oznaczało ,,zrzucanie (myśli) razem" czyli ,kontrakt, umowe“", dalej umówiony znak, dalej odznakę, noszoną przez sędziów, odznakę dobrowolnie obraną przez przyjaciól i przez nich noszoną na znak przyjaźni. Łaciński wyraz symbolum oznacza to samo (= tessera, niem. Kennmarke), a femininum symbola wyraża datek na wspólną ucztę.

Symbol jest znakiem zmysłowo dostrzegalnym, wyrażającym duchowe lub fizyczne przeżycie człowieka. Toteż pojęcia symbolu używa się częstokroć w bardzo szerokim znaczeniu. Tak np. „Enchiridion symbolorum" jest zbiorem pisanym duchowych prawd i założeń wiary świętej. „Credo" nazywamy symbolem wiary w tym znaczeniu, że w kilku słownych artykułach wyraża podstawowe prawdy wiary, że ono jest ,znakiem“, wyróżniającym chrześcijanina od innych ludzi.

Nas interesuje symbol w specjalnym zrozumieniu, mianowicie jako znak graficzny, który swoją kompozycją, nieraz bardzo prostą, wyraża w sposób zewnętrzny pewną dơmatyczna prawdę religijną ${ }^{3}$ ).

W kulcie religijnym symbol zawiera w przedmiocie i znakach ukrytą treść i łączność z życiem nadprzyrodzonym. Myśl Boża bowiem najczęściej dociera do nas przez znaki zewnętrzne.

Symbol więc w ogólności nazwać można znakiem zmysłowym rzeczywistości niewidzialnej. Symbol zaś chrześcijański to zmysłowy znak rzeczywistości nadprzyrodzonej $\left.{ }^{4}\right)$.

\section{Cel, jakiemu służyly symbole liturgiczne.}

Pierwszorzędny cel, dla którego stosowano w życiu pienwszych chrześcijan symbole, był wybitnie dydaktyczny. Był to jeden z bardzo poważnych środków pastoralnych. Najgłębsze prawdy były wyrażane symbolami, by poprzez te znaki widzialne zwracać bezustanną uwagę na prawdy głoszone w nauce Kościoła i na nadprzyrodzoność realną,

$\left.{ }^{2}\right)$ „Rien n'entre pas dans l'intelligence, qui ne passe d'abord par les: sens". Dictionnaire du symbolisme. Paris 1936, str. 3.

$\left.{ }^{3}\right)$ Ks. A. Nowowiejski, Wykład liturgii Kościoła katolickiego, Warszawa 1893, t. I, str. 21.

$\left.{ }^{4}\right)$ „Un symbole en général est le signe sensible d'une réalité invisible, un symbole chrétien, le signe sensible d'une réalité, mystique, sacrée“. Diction-. naire du symbolisme, str. 3 . 
chociaż w tym życiu niewidzialną. Pienwsze wieki nie znały połowiczności. Całe życie było wybitnie chrystocentyczne. Prawdy Boże, ich zgłębianie, poznawanie i realizowanie, były celem życia człowieczego nade wszystko. Toteż każdy dom, a w nim prawie każdy przedmiot nosił sty.gmat myśli Bożej. Szaty, naczynia, ozdoby, kaganki, listy, każda księga była znaczona jakimś znakiem świętym. Wszystkie zaś one miały przywodzić na myśl Chrystusa, ucząc najgłębszych tajemnic wiary świętej, w niej utwierdzać i do niej zachęcać. Zgłębianie treści symbolów było obowiązkiem każdego wierzącego. Były one bowiem jednym ze środków nieodzownych duszpasterstwa. Toteż św. Augustyn gani tych, co nie znają symbolów w ich wewnętrznej treści. „Podobni są do nieuków, którzy czytać nie umieją, a podziwiają tylko piękno liter" $\left.{ }^{5}\right)$.

Z pietyzmem więc zachowywano symbole, tłumacząc pełnię ich treści. Rozwijano je i zewnętrznie zdobiono najkosztowniejszymi kamieniami, bo były klejnotami myśli ze skarbca prawd Bożych. Jak dogłębnie znano ich treść, świadczy fakt, że stosowano je z wielką celowością w sztuce kościelnej. W mauzoleach dominowała w nich idea nieśmiertelności duszy, zwrot ku życiu wiecznemu, pozagrobowemu, ku transcendentalności prawd Bożych. Bazylıki znowu symbolami kierowały myśl ku Zbawcy, Najświętszej Marii Pannie, czy męczennikom. Dowodem, że ich użyteczność była coraz większa jest fakt, że z początkowych kilku zaledwie symbolów liczba ich wzrastała do setek, posługując się dla wyrażenia prawd Bożych wszelkimi możliwymi rzeczami, niebem i ziemią, aby coraz lepiej wyrazić i szerzyć chwałę Bożą.

4. Symbol Chrystusa w znaku krzyża św.

Najbardziej znanym symbolem chrześcijańskim jest krzyż, składający sie z linii poziomej i pionowej, które się prostopadle i proporcjonalnie przecinają. Jest to typowy symbol Chrystusa, a św. Augustyn mówi wyraźnie: „Postremo quid est signum Christi nisi crux Christi“ $\left.{ }^{6}\right)$. Krzyż był znakiem hańby u pogan i żydów. Chrześcijanom zaś uprzytamniał Zbawiciela. Symbol ten w tym sensie był znany dopiero po Konstantynie Wiekim i jako najistotniejszy bodaj ze wszystkich przetrwa do końca świata. Wyznawcy Jezusa czcili Gro przez kilka wieków bez postaci Ukrzyżowanego. Późniejsze wieki dopiero uwi-

$\left.{ }^{5}\right)$ Św. Augustyn, Serm. 48, Migne, P. L. 88, str. 592.

$\left.{ }^{6}\right)$ Tract. 118,5 . 
daczniają na nim Chrystusa (V w.) ${ }^{7}$ ), początkowo jednak bez oznak męki, które pojawiają się dopiero od w. 11 (cyfr. ibid.). Współcześnie zaś znany jest raczej krzyż z wizerunkiem Jezusa cierpiącego.

Wydaje się jednak, że istotnie sam krzyż jest znaicznie wymowniejszy, aniżeli w połączeniu z pasyjką Chrystusa. Kiedy bowiem krzyż z Ukrzyżowanym jest symbolem cierpienia, to krzyż w ogóle jako znak jest symbolem chwały, zwycięstwa, łaski, życia, zmartwychwstania i cierpienia zarazem. Tutaj tė̇ należy szukać w dużej mierze przyczyny, dla której chrześcijanie tyle wieków obywali się bez wizerunku Chrystusa, przybitego do krzyża. Droga cierpienia była dla nich normalną droga, wyznaczona przez samego Mistrza do zbawienia. Niczego bowiem więcej, jak cierpienie na tym świecie nie obiecywał: „Jeśli was świat znienawiidzi, wiedzcie, że mnie znienawidził pierwej, niż was" (Jan 15, 18). „Jeśli mnie prześladowali, i was prześladować będą“ (Jan 15, 20) ; ,...będziecie płakać i narzekać, a świat się będzie weselił" (Jan 16, 20). Realizm tej prawdy przeżywali od pierwszej chwili zetknięcia się $\mathrm{z}$ nauką i wiarą Chrystusową. W tych czasach cierpień i prześladowań była im potrzebna moc zwycięstwa, wiary niezłomnej i męstwa, wszystkie te prawdy odezytywali $z$ gołego krzyża. W tym duchu otoczono go też niezwykłą pieczołowitością. Zdobiono kosztowną mozaiką lub drogocennymi klejnotami, by był wyrazem łask, siły duchowej, którą nas obdarzył Zbawiciel. Podobnie bowiem jak klejnoty są źródłem blasku i promieni, tak i Chrystus poprzęz Odkupienie przyozdobił duszę naszą klejnotami sakramentów św., promieniejących łaskami. Otoczono krzyż kołem, które jest symbolem nieskończoności, by wyrazić wieczność i Bóstwo Jezusa Chrystusa (rys. 1). To znowu przekształcono pionową linię krzyża na grecka literę $\mathrm{P}$, a sam znak krzyża oglądano jakoby z ukosa widząc greckie X. Połączono w ten sposób z znakiem krzyża monogram Chrystusa, czyli dwie litery greckie Imienia Chrystusowego (rys. 2 i rys. 18). Jest to t. zw. znak Konstantyna, datujący się z IV w. Cesarz Konstantyn według podania ujrzał na niebie symbol Chrystusa we formie X P i usłyszał głos, że w znaku tym zwycięży w walce $\mathrm{z}$ nieprzyjacielem. Tego znaku tė̇ używał cesarz. Chrześcijanie zaś z biegiem lat zastąpili go znakiem krzyża i inicjałami dosłyszanych słów.

Tajemniczość tych znaków religii prześladowanej nie winna budzić zagadkowości, a raczej ujmujące zdumienie nad tym, jak sobie nieraz w bardzo prosty sposób przypominano głębokie prawdy. Innym

7) Lexikon für Theologie und Kirche, t.VI, str. 247. 
razem podkreślano czterokrotnie krzyż, jako wyraz faktu, że prawda o Jezusie Chrystusie jest wsparta na wiarogodnych faktach podanych przez czterech Ewangelistów (rys. 3). To znów dodawano do krzyża cztery przekątnie, zdobywając litere X -- pierwsza imienia Chrystusowego i upatrując w tym znaku nierozłączność prawdy Krzyża z prawd? Chrystusową (rys. 4 i 5 ). U ramion krzyża uczepiano grecką literę alfa i omega (rys. 6 i 7), by uzmysłowić wypowiedź Zbawiciela, że jest początkiem i końcem wszechrzeczy (Apokal. 21, 6).

U stóp krzyża umieszczony wąż (rys. 8) symbolizował Chrystusa jako pogromcę grzechu pierworodnego i zła. W symbolu Trójcy Przenajświętszej centralne miejsce zajmował także znak Chrystusa (rys. 9) krzyż.

Prosty krzyż był także wymownym znakiem jedności sił Boskich i ludzkich w Chrystusie. Linia pozioma była od dawien dawna oznaka ziemskich wartości ${ }^{8}$ ), podobnie, jak pionowa symbolizowała moc działania Boskiego na świat. Toteż te dwie przecinające się linie symbolizowały zjednoczenie natury Boskiej i ludzkiej, tajemnicę wcielenia, a zarazem myśl praktyczną na codzień, że tylko natura i nadnatura, przyrodzoność i nadprzyrodzoność, ciało i duch, człowiek i Chrystus składają się na pełnię naszego człowieczeństwa.

Jaką czcią otaczano ten najistotniejszy symbol Chrystusa dowodem jest fakt, że św. Paulin odbudował w IV w. bazylikę św. Feliksa w Rzymie ${ }^{9}$ ), a nad wejściem, na środku absydy umieścił krzyż złoty, zdobny kamieniami. W tej samej bazylice umieścił nadto krzyż zdobiony perłami, to znowu wieńczyć kazał inny laurami, czy umieścić w witrażach.

Odmiany krzyża, jakie spotykamy w starożytności, nie wnoszą do myśli chrześcijańskiej, za małymi wyjątkami, niczego szczególnego. Znany jest tak zwany krzyż masztowy (rys. 10), kwadratowy (rys. 11), wschodni (rys. 12), czy też św. Andrzeja (rys. 17).

Bardzo rozpowszechniony był znak krzyża św. w kształcie litery T (rys. 13). Według Ezechicla ${ }^{10}$ ), a później i w Apokalipsie św. Jana czytamy, że wybrańcy Boży byli na czole znaczeni tą grecką literą tau. W starożytności chrześcijańskiej budził ten symbol radość wybrania nas przez Chrystusa do życia wiecznego w Nim. W Egipcie spotykamy go

8) Koch, Das Zeichenbuch, Lipsk 1936, str. 6 .

9) Wilpert, Die römischen Mosaiken und Malerien der kirchlichen Bauten, Freiburg 1917, I, str. 45.

${ }^{10}$ ) Ezechiel 9, 4. - Por. też „Ruch Bibl. i Lit. I nr 1, str. 148: „Nasz znak“. 

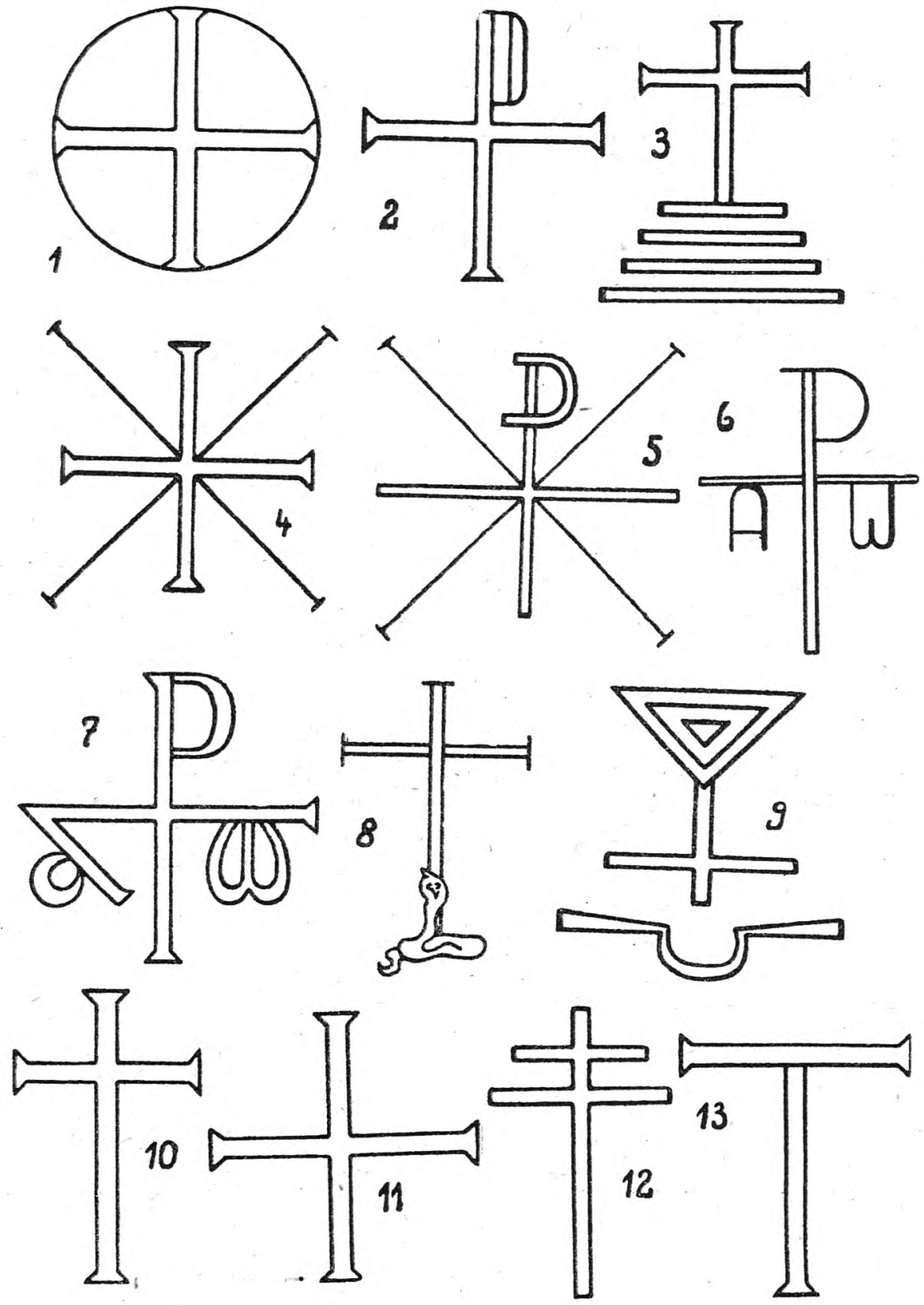
w nieco odmiennej formie (rys. 14), którą zwią ankiem, krzyżem kluczowym, który w alfabecie hieroglifowym oznaczał, ,życie“. Podobnie bowiem wyglądał klucz, za pomocą którego otwierano śluzy Nilu. Jeżeli klucz ten był środkiem, za pomocą którego wody użyźniały doliny Nilu, przynosząc życie i plon, podobnie w symbolice znak T (tau) symbolizuje Chrystusa, który przez krzyż otworzył dla ludzkości zdroje łask, dając jej możność owocnej pracy i zdobycia nieba. Jak bardzo pociagającym był ten symbol wybrania i łask Chrystusowych, świadczy i to, że późniejsze wieki umieściły go wśród fal i ryb (rys. 15) ${ }^{11}$ ).

Ta sieć Łowcy dusz - Chrystusa - jest ratunkiem dla nas ludzi, t. j. ryb, ${ }^{12}$ ) wśród burzliwego życia. Równie wymownym jest krzyż kotwiczny o podobnym pochodzeniu. Oznacza Chrystusa, naszą jedyną nadzieje (kotwica) i jedyne źródło prawdziwego pokoju (rys. 16).

\section{Monogramowe symbole Chrystusa.}

Znany nam już jest monogramowy krzyż (rys. 2), który pojawia się zaraz w I wieku.

Najpierwotniejszymi symbolami Chrystusa jednak to litery, składające się na Jego imię. Tak to mówi o Nim grecka litera $X$, jako pierwsza rozpoczynająca wyraz XPISTOS Chrystus (rys. 17). Podobnie symbolizują nam Jego imię dwie pierwsze litery złączone mono gramowo X i P (rys. 18). Jedni widzą w tym znaku także symbol pokoju „Pax“, chociaż jest to późniejsze i swobodniejsze tłumaczenie, kiedy litery gı eckie czytano jako łacińskie. Pierwsi chrześcijanie doczytywali się w tym znaku brzmienia imienia Chrystusa, jak to analityoznie pokazuje rys. 19. Wilpert jednak twierdzi, że trzeba ku temu dużej dozy fantazji. Jeżeli się jednak zważy, że to są tajemne znaki prześladowanych, to fakt ten zdaje się wiele tłumaczyć. Albowiem pewna tajemniczość na tym właśnie polega, by niedociągnięcia w wyrażalności oczywistej znaku były dlań charakterystyczną cechą. Ten sam monogram $\mathrm{z}$ doczepieniem pierwszej $\mathrm{i}$ ostatniej litery alfabetu greckiego był symbolem chrystocentrvzmu życia ludzkiego (rys. 20). Chrystus bowiem w najściślejszym i najpełniejszym tego słowa znaczeniu winien być dla nas wszystkim. Równie wymowny, a głęboki za-

11) Liturgical Symbols, Minnesotta 1943, str. 8 .

12) Tertulian, De bapt. 1: „,nos piscipuli... in aqua nascimur“. Por też Lexikon f. Theol. u. Kirche“ IV, 19 i wspaniałą monografię Ks. Dölgera: Ichthys. Das Fischsymbol der frühchristlichen Zeit, I-III (1910-1922). 


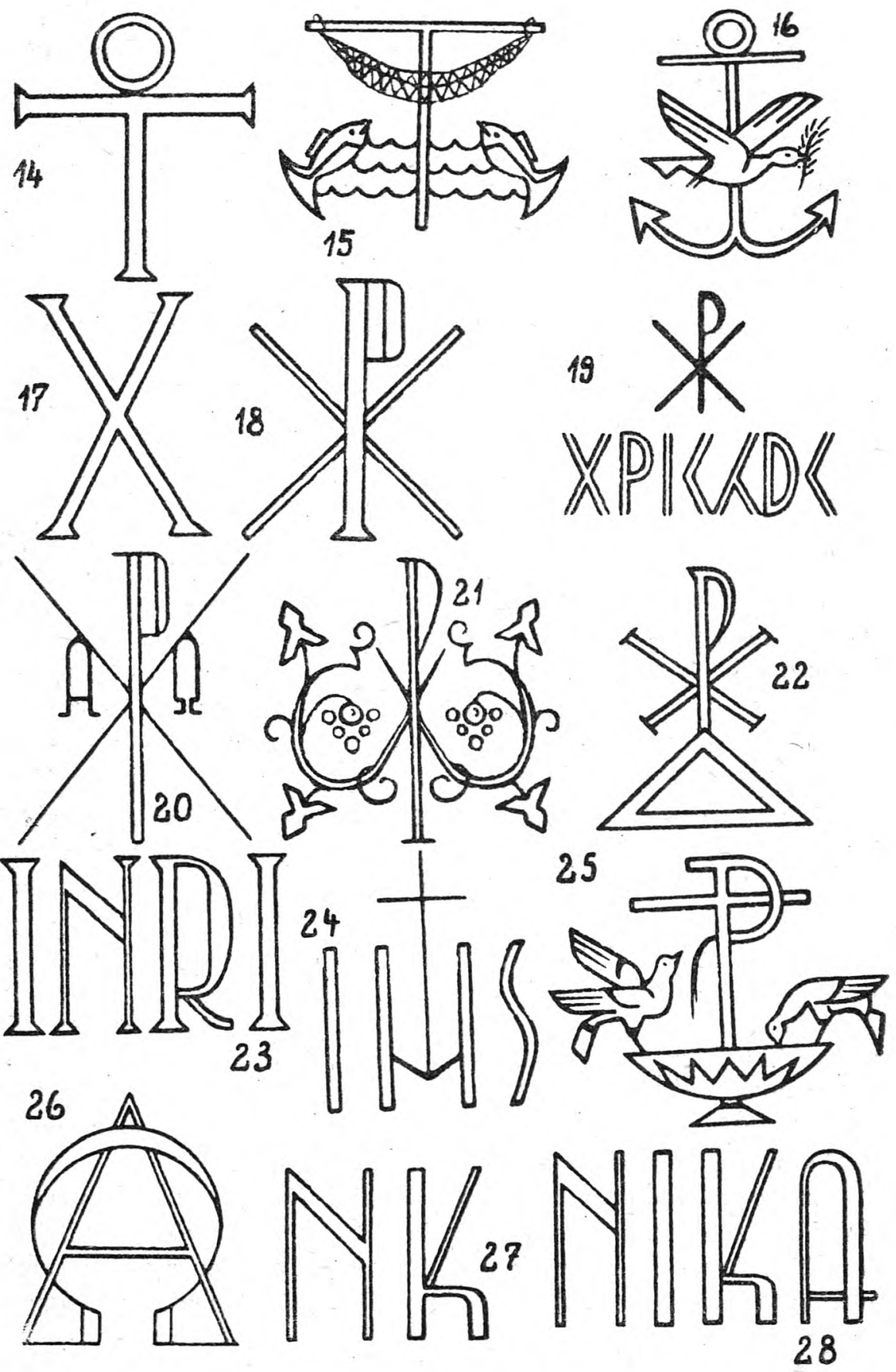


razem jest symbol zespolony latoncślą winną. Wskazuje on na organiczną łączność naszą z Jezusem Chrystusem w Jego Mistycznym Ciele. „Ja jestem winnym krzewem, a wy latoroślami..." (Jan 15, 5-7) (rys. 21).

Do monogramowych symbolów Chrystusa zaliczyć też można znaki złożone, jak na rys. 22. Monogram Chrystusa, wsparty na trójkącie równobocznym, który jest znakiem Trójcy Przenajświętszej, symbolizuje tajemnicę odkupienia, jako dzieła Trójjednego Boga. Powszechnie też jest znany symboliczny znak Chrystusa, wynikający $\mathrm{z}$ napisu, umieszczonego na drzewie krzyża św.: Jezus Nazareński Król Żydowski — INRI (rys. 23), t. j. Iesus Nazarenus Rex Iudaeorum (Jan 19, 19). Do najezęściej spotykanych symbolów liturgicznych należy napis IHS (rys. 24). Jest to bodaj symbol, o którym bardzo wiele dyskutowano w związku ze słynnym Labarum i jego wyglądem; jedno jest pewne $\mathrm{i}$ to nas najbardziej w tym wypadku interesuje, że cały sens jego leżał właśnie w tym, iż tylko w Chrystusie, leży zwycięstwo. IHS jest zestawieniem pierwszych trzech liter greckich imienia Jezus. Później dopiero, uważając litery te za łacińskie czytano je jako skrót: ,in hoc signo (vinces). Toteż legenda „In Hoc Signo“ przy krzyżu pochodzi dopiero z VI lub VII w. i oznacza myśl, że jedyne zwycięstwo w zmaganiu się z przeciwnościami jest tylko w Jezusie Chrystusie.

Obrazowo piękny i treścią bardzo wymowny jest krzyż wsparty na czasze kielicha (rys. 25). Krew spływa z krzyża, a wierni (gołębice) czerpią posilenie. To symbol ofiary Chrystusowej i jej nieodzowności dla naszego zbawienia, to symbol do słów Chrystusa: „Pijcie z tego wszyscy. To jest bowiem kielich krwi mojej Nowego Testamentu“" (Mat. 26, 27).

Wspominaliśmy już w związku z rys. 20, że do monogramowego znaku Chrystusa doczepiano greckie litery alfa i omega. Używano ich także jako oddzielnego symbolu (rys. 26). Zwracał on uwage, jak zresztą kilka już innych, na chrystocentryzm naszego życia od początku do kresu dni, w myśli i czynie. (Apokalipsa XIII, 13). Jest to również symbol boskości posłannictwa Chrystusowego, Jego nieomylności w nauce $\mathrm{i}$ wiary i to pod każdym względem ${ }^{13}$ ).

Często też spotykamy u pierwszych chrześcijan symboliczny napis grecki NIKA (od greckiego ozasownika nikaejn, tj. zwyciężać) lub jego skrót NK. Oznacza on zwycięstwo (27 i 28). To jeden z najstarszych znaków udręczonych chrześcijan, których krzepił ten wyraz, wskazu-

${ }^{13}$ ) Por. „Ruch Bibl. i Lit.“ I, nr. 1, str. 48. 

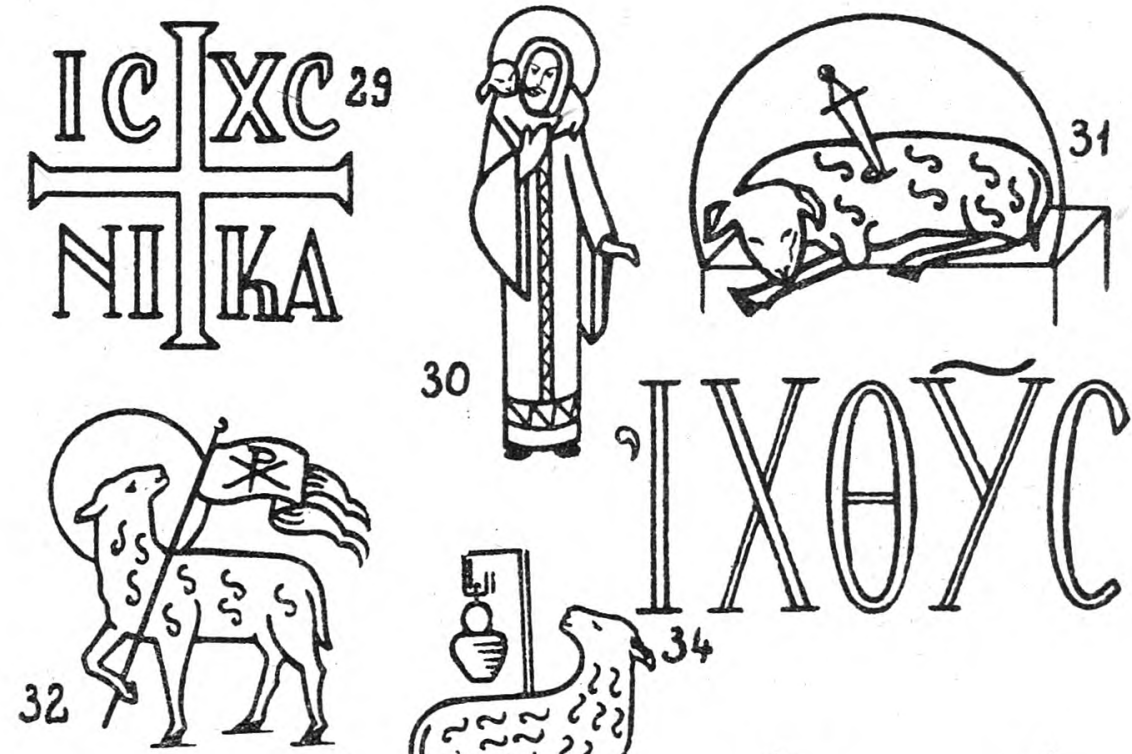

30
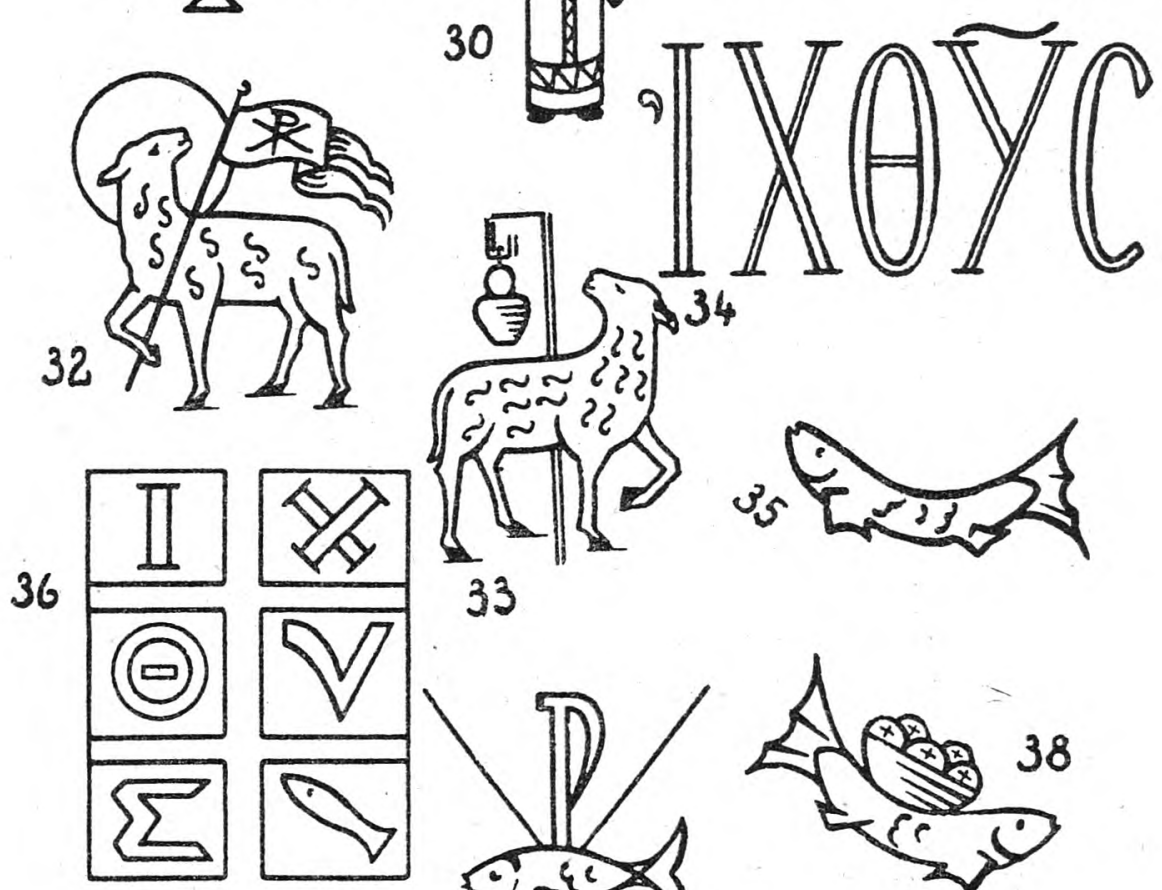

33

(1904c5
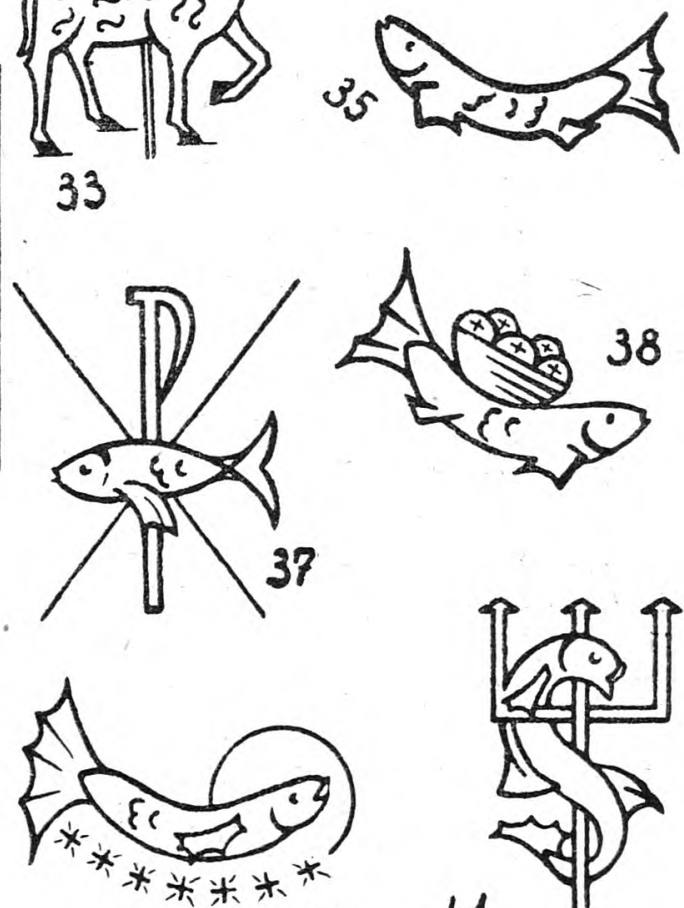
jący na Chrystusa jako Zwycięzce wszelkiego zła. Bardziej jeszcze pełnym w wymowie i pięknie jest symbol Chrystusa we formie krzyża wraz z pierwszą i ostatnią literą dwóch imion Zbawiciela, pisanych alfabetem greckim: Jezus - IC, Chrystus - XC, Zwycięzca - Nika (rys. 29). Symbol ten zawierał więc bardzo mocną prawdę, że Jezus Chrystus jest Zwycięzcą.

Niezapomnianym jest dla każdego chrześcijanina obraz z Ewangelii o Dobrym Pasterzu (Jan 10,11). Spotykamy go również od zarania chrześcijaństwa (rys. 30). Wraca on w sztuce katolickiej niezliczone razy. Podobnie ozęstym symbolem jest baranek przebity mieczem i złożony na ołtarzu całopalnym. Jest to symbol Chrystusa i Jego niewinnej ofiary za nasze grzechy (rys. 31).

Do dzisiejszego dnia znany jest symbol Chrystusa Zmartwychwstałego, przedstawionego $\mathrm{w}$ baranku $\mathrm{z}$ chorągiewką (rys. 32). Rzadziaj dziś, lecz w starożytności chrześcijańskiej często spotykany był obraz baranka $\mathrm{z}$ laską pasterską, u której uczepiono dzbaneczek. Jest to symbol Jezusa Chrystusa, Dobrego Pasterza, który pełen łagodności, czystości i cierpliwości strzė̇e i kạrmi Swoją trzódkę (rys. 33).

\section{Ryba, jako symbol Chrystusa. ${ }^{14}$ )}

Od początków chrześcijaństwa była ryba znanym symbolem Chrystusa, a to $z$ prostej przyczyny. W języku greckim ryba znaczy ichtys (rys. 34 i 35), a każda $\mathrm{z}$ tych pięciu liter początkuje najbardziej istotne określenia Boga Człowieka, a mianowicie: Jesus - Christos Theu - Hijos - Sôtêr = Jezus, Chrystus, Syn Boga, Zbawiciel. Spotykamy np. symbol, który na sześciu polach rozrzucił poszczególnych pięć liter, a w szóstym umieścił rybę, jakby tłumacząc znaczenie całości (rys. 36). Był to jeden z najbardziej ulubionych symbolów, a zarazem najczęściej używanych. Mimo bowiem wielkiej prostoty, mówił wyznawcom bodaj najwięcej. Z lubością przedstawiano ten symbol w różnych formach i tak umieszczano rybę na tle monogramowego symbolu Chrystusa (rys. 37). To znowu przedstawiano ją z koszem chlebów na plecach, co miało przypominać Chrystusa Eucharystycznego, jako dawce pokarmu niebieskiego (rys. 38). Innym razem zdobna była w napis, który wtajemniczonym mówił o Jezusie Chrystusie, Synu Bożym i Zbawicielu (rys. 39). Jak popularny był symbol ryby, świadczy fakt, że spotykamy go na medalionach, kagankach, rzeźbach,

14) Por. wyżej cytowaną monografię Ks. Dölgera. 
polichromiach. Dla pogan i żydów ryba nie miała żadnego symbolicznego znaczenia. Ten fakt właśnie ułatwiał używanie symbolu, a zarazem prostota i głębia, typowały go na szczególnie umiłowany i częstokroć stosowany znak. Rzadziej spotykano rybę jako symbol Chrystusa - Dawcy siedmiu Sakramentów św. (rys. 40).

Do tej grupy symbolów należy zdaje się zaliczyć także symbol Chrystusa, wyrażany częstoḳroć pod postacią delfina na trójzębie. Ryba ta była w starożytności symbolem przyjaźni, ratunku dla tonących, towarzysza wiernego na dalekich wędrówkach i wyrazem piękna. Trójząb zaś przypominał wyglądem krzyż. Czyż ten znak nie nadawał się doskonale, by go przenieść na grunt myśli chrześcijańskiej? Albowiem jako wybitnie pogański nie budził żadnych podejrzeń (rys. 41). Chrześcijanie zaś wkładali weń nową treść o transcendentalnej wartości i głẹbi myśli o Jezusie Chrystusie.

\section{Symbolika światła. ${ }^{15}$ )}

Światło miało w ogóle wielkie znaczenie w liturgii od zarania chrześcijaństwa i symbolizowało Chrystusa w radości, chwale i prawdzie. Śladem tego są chociażby świece płonące przy udzielaniu sakramentów św. Jest to zwyczaj pełen głębokiej myśli, a Kościół św. zoborwiązuje przepisem do używania światła przy liturgii. Przy czytaniu Ewangelii akolici niosą światło. Świeca zaś ma swój głęboki sens. Podobnie jak przy gromnicy rozróżniamy trzy części składowe, t. j. wosk dziewiczej pszczoły, knot przeznaczony do palenia i na spalenie, oraz światło, zasilane tymi dwoma składnikami, tak też w cudowny sposób zrodzone $\mathrm{z}$ Dziewicy ciało Chrystusowe jest osłona Jego duszy, a razem wziąwszy, narzędziem Boskiej natury. ${ }^{16}$ )

Najbardziej znanym, a dziś już mało zrozumianym svmbolem jest Paschał (rys. 42). Liturgia sama najwymowniej określa symbolike paschału. We Wielkim Tygodniu gasną wszelkie światła. Zapłonie na nowo w Kościele paschał, od którego zapali się resztę świec. To wyraz obumarcia Starego Zakonu i wspomnienie śmierci Proroków i sprawiedliwych, którzy od Abla począwszy żyli tęsknotą za przyszłym Mesjaszem. ${ }^{17}$ ) Dopiero Zmartwychwstanie przyniesie i przynosi dla każdego

15) Por. prace Ks. Dölgera: Sol Salutis (1922) i Die Sonne der Gerechtigkeit (1918).

16) Hugo de S. Vict.:'Miscel. II, lib. 4, c. 9 (Opp. III. 222).

${ }^{17}$ ) Por. Sauer, Symbolik der Kirchengebaüdes und seiner Ausstattung in der Auffassung des Mittelalters, 1924, str. 189. 
pokolenia zaczątek nowego życia w światłości i prawdzie w Jezusie Chrystusie. Zapalony zostaje paschał płomieniem, który powstał z iskier krzesanych kamieni, czy kryształów na wspomnienie Chrystusa, który jest podwaliną Kościoła o krystalicznie czystej duszy bez win. Benedykuje go diakon. Podobnie też i istota słabsza zwiastowała Zmartwychwstanie, a nie Apostołowie. Słuszną bowiem jest rzeczą, by kobieta, która przyniosła upadek na świat, zwiastowała mu odkupienie.

Exultet wyraźnie mówi, że paschał jest symbolem zwycięstwa, łuną chwały, lśniącym odrodzeniem, strugą prawdy, żarem duszy, który gładzi grzechy. Ma on być znakiem zmartwychwstania, rozsłonecznieniem dni naszych, świat?em i rozkoszą serca w Jezusie Chrystusie ${ }^{14}$ ). Tak pięknie śpiewa symbolikę paschału jeden $z$ najpiękniejszych hymnów naszej liturgii. Sumarycznie więc paschał jest symbolem prawdy o Jezusie Chrystusie Zmartwychwstałym i ma być praktycznym corocznym przypomnieniem i przė̇yciem tych samych prawd w naszym życiu wewnętrznym. Pięć ziarn wosku przypomina rany Chrystusa.

Każda świeca, każdy płomyk w liturgii jest symbolem życia w Chrystusie, znakiem samego Zbawiciela, który Swoją nauką przywiódł nam myśl o powstaniu tego właśnie symbolu. ,W nim było życie, a życie było światłością ludzi“ (Jan 1,4); ,Jam jest światłość świata“ (Jan 8, 12); ,Niegdyś bowiem byliście ciemnością, a teraz staliście się światłością w Panu“ (Eph. 5, 8) ; ,Bóg jest światłością i nie masz w Nim żadnych ciemności“" (I Jan 1, 5).

Kaganek był często używanym sprzętem w liturgii pierwszych chrześcijan, oświetlając mroki katakumb. Równocześnie jednak symbolizował Chrystusa, dawcę wiary i życia, oraz całkowitej ofiary za ludzkość. Pơdobnie jak oliwa spala się do ostatka, podobnie i Chrystus ofiarował się dla nas bez reszty, byśmy zdobyli światło prawdy, życie nadprzyrodzone (rys. 43). Pochodnym symbolem jest zapewne graficzny znak w kształcie krzyża, złożonego $\mathrm{z}$ greckich wyrazów fôs, zôe, co znaczy światło, życie (rys. 44).

\section{Inne symbole Chrystusa.}

Poza dotąd przytoczonymi, znane są jeszcze inne symbole, które pojawiają się we formach jednostkowych, bez szozególnych odmian.

Takim symbolem jest ,phoenix“. Podobnie, jak delfin jest $\mathrm{i}$ on pochodzenia greckiego. Mitologia grecka widziała w nim symbol nie-

$\left.{ }^{18}\right)$ Ks. Karyłowski Tad. T. J., Hymny Kościelne, Kraków 1932, str. 311. 

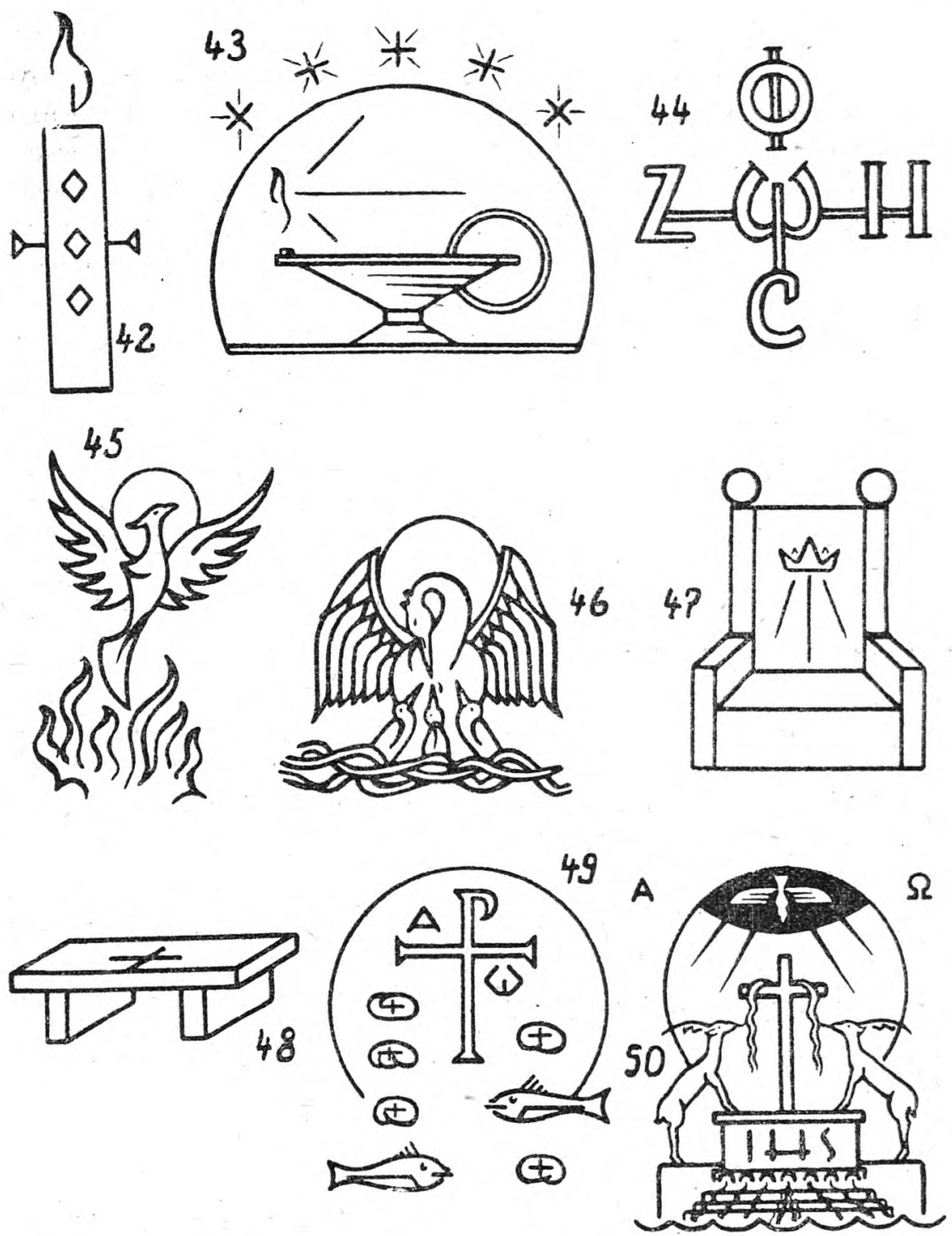

śmiertelności, odradzał się bowiem spalany słońcem z własnych, popiołów. Podobnie i Chrystus płonąc nieustanną miłością dla ludzkości, wiecznie nas ją darzy, a my, spalając się w miłości Bożej zmartwychwstajemy z popiołów własnych słabości đ̊o życia wiecznego (rys. 45).

Pelikan, karmiący, jak sądzono, własną krwią pisklęta (rys. 46) jest również symbolem Chrystusa, który karmi nas własną krwią, dając nam życie wieczne. 
Tron $\mathrm{z}$ insygniami królewskimi (rys. 47) jest tak samo symbolem Chrystusa Króla i Pana wszechrzeczy, dla którego dusza nasza ma być godnie przygotowanym tronem, z którego Bóg obejmie królowanie nad życiem čzłoẉieka. Przymioty królewskie były bardzo często wspominane u pierwszych chrześcijan w stosunku do Zbawiciela, a święto Chrystusa Króla; wznawiające ten kult w ostatnich dziesiątkach lat, znajduje źródłowe uzasadnienie właśnie w pierwszych wiekach chrześcijaństwa.

Ołtarz jest także symbolem Chrystusa (rys. 48). O. Pius Parsch ${ }^{{ }^{19}}$ ) pisze, że okadzanie ołtarza jest aktem uwielbienia i adoracji dla Chrystusa, którego symbolizuje.

Wspomnieć jeszcze należy niezliczoną ilość symbolów, które powstają przez odpowiednie zestawienie wspomnianych znaków symbolicznych. Żywotność kultury, sztuki i liturgii chrześcijańskiej jest tak ogromna, że prawdy wiary św. wyraża częstokroć w coraz to nowych formach, kompilując przeróżne symbole. Przykładem niech będą chociażby dwa symbole złożone, mówiące nam o Chrystusie. Rysunek 49 symbolizuje nam prawdę o Chrystusie Eucharystycznym, który poprzez cudowane nakarmienie rzesz nie tylko każe nam wspominać tę historyezną chwilę N. Testamentu, ale każe rozumieć i żyć faktem, że jest pokarmem dla naszej duszy. Spożywanie zaś tego pokarmu, pozwala nam realnie żyć w zasięgu życia Bożego, które powinno przepajać wszystkie nasze dni od początkụ do końca.

Równie wymowna jest druga kompozycja rysunku 50. Oznacza ona ofiarę Chrystusową ponawianą we mszy św. Jest to jedyna i centralna ofiara Nowego Zakonu (alfa, omega). Z ofiary krzyżowej spływają potoki łask, które koją pragnienie wiernych - jeleni u źródeł (Ps. 41, 1) ${ }^{20}$ ) U podnóża ołtarza wypływa siedem zdrojów łask sakramentalnych.

9. Znaczenie symbolów dla odrodzenia życia religijnego.

Pięćdziesiąt symbolów Chrystusowych w dalekim stopniu nie wyczerpuje $z$ tej dziedziny całego skarbca. Sa to w większości symbole zasadnicze z pominięciem dużej illości pochodnych. Ten szereg znaków

19) Pius Parsch, Wtajemniczenie w ofiarę mszy św., 1947, str. 71. Boże“.

${ }^{20}$ ) „Jak jeleń pragnie źródel wód, tak dusza moja rwie się do Ciebie, 
ze starożytności chrześcijańskiej przywodzi nam na myśl fakt, że każdy z. nich zawierał w sobie jakąś głęboką prawdę teologiczną. Albowiem każdy dogmat posiada w symbolice paralelny znak ${ }^{21}$ ). Nie chodziło jednak tylko o to, by prawdę wyrazić symbolem w pewnym dla oka miłym skrócie, lecz raczej poprzez syntetyozną formę, jaka charakteryzuje symbol, pobudzić myśl ludzką do zastanowienia się nad głębią i wzniosłością prawdy. Zasadniozym jednak celem było, by nie tylko stale przywodzić na myśl prawdy Boże, ale żeby przemyślane wpływały na wolę i umacniały ją na drodze do doskonałości.

Rozpatrując zagadnienie historyczne, należy zaznaczyć, że symbole są bezsprzecznym i pięknym dorobkiem sztuki, kultury i myśli chrześcijańskiej pierwszych wieków. Praktycznie jednak rozpatrzyé trzeba wpływy, jakie mogły i winny wywrzeć na współczesne nam życie wewnętrzne katolików. Św. Tomasz twierdzi, że znaki St. Testamentu mają zupełnie inne znaczenie od symbolów N. Testamentu. Tamte bowiem wskazywały na Jezusa Chrystusa, na przyszłość odkupienia, chrześcijańskie zaś symbole nie wskazują na przeszłość, ani też tyle przyszłość, ile na rzeczywistość faktu odkupienia. Ta rzeczywistość i teraźniejszość prawd musi każdego fascynować, a po namyśle zobowiązywać do konsekwencji czynu wynikającego z przemyślanej rzeczywistości.

Należy stwierdzić, że symbole są współczesnym katolikom bardzo mało znane, toteż jednym $\mathrm{z}$ pierwszych obowiązków duszpasterskich byłoby zapoznanie wiernych z prawdami Bożymi, wyrażonymi w znakach świętych. We wielu świątyniach znajduje się tu i ówdzie jakiś symbol, nieznany prawie nikomu $\mathrm{z}$ wiernych. Można by rozpocząć tłumaczyć najprostsze symbole eucharvstvczne, które są bodaj na każdym tabernakulum, na ścianach presbiterium. Byłaby to doskonała lekcja pokazowa. Pomocą służyłybv gotowe ozdoby własnego kościoła. Tą drogą własna świątynia parafialna stawałaby się bliższa, zrozumialsza i przytulniejsza dla wiernych.

Symbolika może doskonałym być środkiem w nauce religii nawet w najniższych oddziałach. Proste symbole do kredkowania, byłyby miłym i pożytecznym zajęciem dla najmniejszych. Jak łatwo im wtedy wytłumaczyć, co oznacza krzyż, czy koło i t. p. W kościele można by z nimi odszukiwać poszczególne znaki święte, nauczyć wyrażać pewne prawdy wiary we formie lub symbolu. Młodzież zaś bardzo łatwo poj-

$\left.{ }^{21}\right)$ Por. Dictionnaire du symbolisme 3 . 
muje w związku z dogmatyką, czy liturgiką prawdy teologiczne wyrażane w symbolach.

Doskonałą okazją szenzenia poznawalności symbolów jest udzielanie Sakramentów św. Pamiątki, czy książeczki należałoby coraz częściej ozdabiać symbolami, a wręczając je, pouczyć kilkoma słowami o ich znaczeniu. Nie ma bowiem Sakramentu niewyrażalnego symbolem.

Symbolika winna mieć także duże zastosowanie w dziedzinie sztuki stosowanej. Współczesny nam deformizm raczej profanuje kościoły, aniżeli wyposaża w dzieła sztuki. Pęd do prostoty formy szczególnie jest podatnym momentem, by do rąk artystów dać symbole chrześcijańskie. Albowiem wtedy dopiero prostota zdobędzie na głębi treści. Każde zdobniotwo, każdv przedmiot w kościele winien byé tą „,res sacra“, by nosił stygmat służby Bożej. Lawka, klęcznik, kropielnica, czy świecznik powinien mieć znamiona, które mówią, że przeznaczony jest na służbę świątyni. Ileby pod tym względem mogła uczynić architektura wnętrza, jeśli chodzi nawet o domy prywatne. Klęcznik, krzyż, obraz, kropielniczka, a nawet wazonik na ołtarzyku domorwym, czy talerz do chleba lub opłatka na stole wigilijnym, wszystko to winno wrócić do domów naszych zdobne w skromne symbole, by wznosić myśl do Boga. Cała dziedzina biżuterii damskiej, lub dziecięcej, obrączek ślubnych, wszystko to domaga się głębszej myśli i większego chrystocentryzmu. Takie znamiona nosiły domy pienwszych chrześcijan, a współczesność ná miejsce pustki i bezsensowności wielu ozdób winna wnieść myśl o Bogu i naszym celu ostatecznym.

Paramentyka tekstylna miałaby duże pole do stosowania symboliki, by zniknęły szaty nieraz niesamowicie bogato haftowane, lecz tchnące równocześnie niezwykłą płycizną myśli. Każda koronka winna wyrażać myśl Bożą, każdy wazonik przypominać Chrystusa. Duszpasterz, nabywając przedmioty, mógłby tłumaczyć sens ozdób liturgicznych i tym samym poszerzać wiedzę litugiczną wiernych.

Czy byłoby to przesadą? Chrześcijaństwo właśnie miało tę specyficzną cechę nie spotykaną dotąd w żadnej wierze, że z całą wyrazistością wskazywało cel człowieczy na tamtym świecie, a wszelka myśl i działanie każde miało być przygotowaniem na wieczność. Z tych istotnych założeń chrześcijaństwo niczego nie straciło jak tylko to, że w praktyce się o tej prawdzie zapomniało. Skoro zaś nieskończona Mądrość i Prawda objawiła się ze względu na nieudolność ludzką 
poprzez niezliczone znaki zewnętrzne, by trafić do wnętrza duszy ludzkiej, to poniekąd Objawienie i chrześcijaństwo zaaprobowało symbole. Naszym zaś obowiązkiem jest, by je starannie poznawać, pieczołowicie pielegnować, a prawdy w nich zawarte wcielać w życie wewnętrzne.

Szczecin

Ks. KAZIMIERZ ŻARNOWIECKI.

\section{KULT SER(A JEZUSOWEGO W LITURGII MSZALNEJ 1)}

Powoli i nie bez przeszkód wywalczało sobie nabożeństwo do Serca Jezusowego właściwe sobie miejsce w liturgii mszalnej. Pierwsza msza wotywna o Sercu Jezusowym została odprawiona w 1689 r. w klasztorze Sióstr Wizytek w Dijon. Formularz mszalny, rozpoczynający się od słów: „Gaudeamus omnes in Domino", ułożyła wizytka Joanna Magdalena Joly. $Z$ biegiem czasu powstawało coraz to więcej formularzy mszalnych, które były dowodem, jak żywo interesowano siẹ liturgiczną stroną nabożeństwa. Oto niektóre $\mathrm{z}$ nich: Venite exultemus Domino... Elegi... Ingrediens mundum... Venite ad me omnes... Msza święta o Pięciu Ranach Chrystusa... Miserebitur... Egredimi... Cogitationes.

Trzy ostatnie formularze doczekały się aprobaty Stolicy Apostolskiej i były, względnie są jeszcze, używane w Kościele.

M i s e r e b i t u r zawdzięcza swoje powstanie Mgr. Bruni'emu i Calvi'emu. Jest owocem decyzji Kongregacji Rytów z dnia 26 stycznia 1765 r., uznającej nabożeństwo do Serca Jezusowego. W dniu 11 maja 1765 r. uzyskał on potwierdzenie wspomnianej Kongregacji. Przedmiotem rozważań tego formularza jest przebite włócznią Najświętsze Serce Jezusowe, którą to scenę opisał św. Jan w rozdz. 19 swej Ewangelii. Całe bowiem nabożeństwo do Serca Jezusowego wyrosło na tle rozważań zranionego boku Jezusowego, jako jednej z Piẹciu Ran Chrystusa. Te rozważania doprowadziły do rany Serca, a w końcu do samego Serca. Gdy w r. 1697 zwróciły się Wizytki do Stolicy Apostolskiej z prośbą o zatwierdzenie dla nich własnej mszy św. o Sercu Jezusowym, motywując to tym, że one (Wizytki), zgodnie z zaleceniami św. Franciszka Salezego, pałają szczególnỵm nabożeństwem do

1) Jest to dalszy ciąg artykułu $z$ „Ruchu B. i L.“ II, zeszyt 2. 